\title{
Erratum to: PARAssign-paramagnetic NMR assignments of protein nuclei on the basis of pseudocontact shifts
}

\author{
Simon P. Skinner • Mois Moshev • Mathias A. S. Hass • \\ Peter H. J. Keizers • Marcellus Ubbink
}

Published online: 23 June 2013

(C) Springer Science+Business Media Dordrecht 2013

Erratum to: J Biomol NMR (2013) 55:379-389

DOI 10.1007/s10858-013-9722-1

Dear Readers,

The complete list of authors should read as follows:

Simon P. Skinner, Mois Moshev, Mathias A. S. Hass, Peter H. J. Keizers, Marcellus Ubbink

We apologize for an oversight in the original publication of the article.

The online version of the original article can be found under doi:10.1007/s10858-013-9722-1.

S. P. Skinner - M. A. S. Hass · P. H. J. Keizers ·

M. Ubbink ( $\square)$

Gorlaeus Laboratories, Leiden Institute of Chemistry, Leiden University, P.O. Box 9502, 2300 RA Leiden, The Netherlands e-mail: m.ubbink@chem.leidenuniv.nl

\section{S. P. Skinner}

e-mail: skinnersp@chem.leidenuniv.nl

M. A. S. Hass

e-mail: hassmas@chem.leidenuniv.nl

M. Moshev

Leiden Institute of Advanced Computer Science, Leiden

University, Snellius Building, P.O. Box 9512, 2300 RA Leiden,

The Netherlands

e-mail: mois@monomon.me 